Review Article

\title{
Point-of-Care Diagnoses and Assays Based on Lateral Flow Test
}

\author{
Miroslav Pohanka \\ Faculty of Military Health Sciences, University of Defense, Trebesska 1575, Hradec Kralove CZ-50001, Czech Republic \\ Correspondence should be addressed to Miroslav Pohanka; miroslav.pohanka@gmail.com
}

Received 26 November 2020; Revised 5 January 2021; Accepted 11 January 2021; Published 20 January 2021

Academic Editor: Adil Denizli

Copyright (C) 2021 Miroslav Pohanka. This is an open access article distributed under the Creative Commons Attribution License, which permits unrestricted use, distribution, and reproduction in any medium, provided the original work is properly cited.

Analytical devices for point-of-care diagnoses are highly desired and would improve quality of life when first diagnoses are made early and pathologies are recognized soon. Lateral flow tests (LFTs) are such tools that can be easily performed without specific equipment, skills, or experiences. This review is focused on the use of LFT in point-of-care diagnoses. The principle of the assay is explained, and new materials like nanoparticles for labeling, new recognition molecules for interaction with an analyte, and new additional instrumentation like signal scaling by a smartphone camera are described and discussed. Advantages of the LFT devices as well as their limitations are described and discussed here considering actual papers that are properly cited.

\section{Introduction}

There are standard laboratory methods (chromatographic, mass, immunochemical, genetical, etc.) suitable for the analysis of various compounds and substances. Although the aforementioned laboratory methods exert superior features, they are quite expensive for both purchasing and cost per one assay. Moreover, education related to the type of analysis or experiences at least are required for staff controlling the instruments.

In the bioanalytical approaches, there is a little different situation to the standard analytical methods in the central laboratories. While the dominant part of analyses is expected to be made in clinical laboratories, it is also necessary to perform some analyses outside. The term point-of-care testing has emerged in current medicine. It can be explained as a simple test suitable to be finished including data evaluation in the home conditions by a patient or by a caregiver with no education in the bioanalyses or similar disciplines. Disposable urine test strips for multiple biochemical parameters and glucose biosensors for a fast glycemia assay can be mentioned as the standard commercial devices. Research on diagnostical biosensors is ongoing, and a number of new biosensor devices suitable for point-of-care testing have been investigated [1-5]. Other types of point-of- care tests like the colorimetric one based on a digital camera are developed [6-9].

The current review is focused on lateral flow immunochromatographic assays also known as lateral flow tests (LFTs) and their use in point-of-care. The LFT has started quite a long ago, and many analytical and diagnostical methods have been developed on the platform. In recent time, further improvement was achieved due to the use of advanced materials like colored nanoparticles. The recent progress in the field of LFT is surveyed here, and the progress is analyzed and discussed. The actual literature on LFT is summarized here.

\section{LFT Development as a Standard Platform}

Various paper tests for measuring a wide scale of parameters like $\mathrm{pH}$ or thin-layer chromatography assay have been extensively researched since the beginning of modern chemistry. Chromatography as a general method is connected with the work of Russian scientist Mikhail Tsvet in the early 1900s, and thin-layer chromatography was first reported by Russian scientists Izmailov and Shreiber in 1938 [10]. Further research on immunoassays including the latex fixation test provided a simple analytical tool significantly 
improving and simplifying the previous methods [11, 12]. The first LFT devices were developed as an outcome of knowledge from previous methods and a series of patents applied in the 1980s. LFTs for proving pregnancy by the assay of human chorionic gonadotropin in urine were the first commercial tests working on the lateral flow principle and using specific antibodies against the hormone [13].

The original types of LFT were based on the recognition capacity of antibodies that served as a recognition part of the assay. The general principle is shown in Figure 1 and can be described as follows: the assay is performed on a sheetshaped matrix from paper, cellulose, etc., that contains freely adsorbed antibodies labeled by color or fluorescent mark and specific against the analyte on the first end. The matrix also contains two zones with immobilized antibodies on the second end: the first zone contains antibodies specific to the analyte, and the second zone immobilized antibodies specific against free-labeled antibodies. A liquid sample is applied on the first end and the analyte presented in the sample interacting with the labeled antibodies. The complex analytelabeled antibody and the unreacted antibodies are carried by the lateral flow on and in the hydrophilic matrix. The complex analyte-labeled antibody is captured on the first zone forming a colored spot visible by a naked eye. The unreacted labeled antibodies interact with the second zone and form a visible spot as well. The coloration caused by an analyte is frequently called the test line, while the spot by unreacted antibodies is frequently called the control line.

As seen from the principle of the LFT, it is a simple method suitable for simple assay relying on a naked eye, no specific instrumentation is necessary, and even liquid sample can be measured directly without further treatment. It is typically suitable for field applications [14]. Though LFT can be called by a synonym lateral flow immunochromatographic assay and antibodies are relevant and are also the most traditional recognition part in them, other recognition molecules fully replacing the antibodies can be also embedded. Aptamers can be exampled [15].

Gravidity tests for semiquantitative determination of human chorionic gonadotropin in urine are well known and are mass-produced types of LFT [16]. However, other types of LFT are currently available in the market, and many of them serve for the purpose of point-of-care diagnosis. The LFT kits for the detection of lipoarabinomannan in urine as a marker of Mycobacterium tuberculosis and diagnosis of tuberculosis disease [17, 18], detection of antibodies responsible for allergic reactions like the antibodies causing allergic bronchopulmonary aspergillosis [19, 20], detection of allergenic substances like peanut and hazelnut in food products [21], diagnosis of coronavirus disease 2019 (COVID-19) including antigens and specific antibodies [22-25], detection of antibodies against Brucella sp. to diagnose brucellosis [26], peste des petits ruminants virus disease diagnosis by antigen detection in fecal and nasal swab samples [27], measuring of $C$ reactive protein in the blood, blood plasma, and serum [28], and assay of biological warfare agents and toxins like Bacillus anthracis, Escherichia coli O157:H7, staphylococcal enterotoxin B, ricin, botulinum toxin, Francisella tularensis, and Yersinia pestis [29-32] can be mentioned as examples of commercially available devices. The appearance of a commercially available LFT is depicted in Figure 2.

The standard methods have a lack in the inability to measure the exact concentration of the analyte, and the assays can be performed as a semiquantitative test only. The spots formed on the LFT matrix are typically narrow which is optimal for coloration scaling by a naked eye but not an ideal solution for colorimetry. Digital cameras including the cameras integrated into smartphones are considered as the future tool for coloration scaling in various analytical protocols [8,33-36]. The assays can be also improved by spot design or by manufacturing more positive spots with an unequal affinity toward analyte placing in the LFT strip, so the concentration of analyte would be better estimated by a naked eye. The next evolution of LFT should be made with regard to the measuring platforms making the formerly qualitative or semiquantitative tests to be the quantitative ones.

2.1. Current Trends in LFT Construction in Point-of-Care Diagnosis. Though the original LFT devices from the $1980 \mathrm{~s}$ are the functional ones, further improvement is desired to improve their analytical specifications and reduce costs. Comparing to the original devices from the 1980s, the currently researched and developed LFT contains typically alterations in selected recognition molecule and substance responsible for the visualization of the interaction with the analyte. Evolution of materials for matrix manufacturing, overall design resolving problems with manipulation by an unskilled worker, and improving LFT package to make it have long-term stability can be mentioned as the other areas of improvement. The evolution of LFTs is not of course related to devices for diagnosis only because the platform gained overall popularity in analytical chemistry and various applications are known for this moment.

The immunoassay-based point-of-care diagnostic tool was, for instance, described for COVID-19. The researchers investigated seroprevalence for COVID-19 using standard enzyme-linked immunosorbent assay (ELISA) and compared it with a standard LFT based on antibodies labeled by colloidal gold [37]. The LFT and ELISA mutually correlated and the authors concluded their work by a recommendation that LFT is suitable for point-of-care in the healthcare setting and COVID-19 monitoring. In another study on COVID19, an LFT device for immunoglobulins (Ig) $\mathrm{M}$ and $\mathrm{G}$ in blood was constructed using selenium nanoparticles labeled SARS-CoV-2 nucleoproteins causing interaction with IgM and IgG antibodies [38]. The assay exerted a limit of detection of $20 \mathrm{ng} / \mathrm{ml}$ for IgM and $5 \mathrm{ng} / \mathrm{ml}$ for IgG in a 10minute lasting assay. Other types of nanoparticles can be also used for an LFT immunoassay. For instance, LFT based on carbon nanoparticles conjugated with $\mathrm{p} 48$ protein was developed for the diagnosis of mycoplasma caused by Mycoplasma bovis [39]. The assay exerted $100 \%$ specificity and no cross-reactivity with antibodies to other bovine pathogens. A full correlation with ELISA was also reached. An LFT test using monoclonal antibodies labeled by gold nanoparticles 


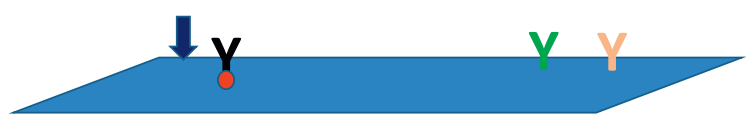

(a)

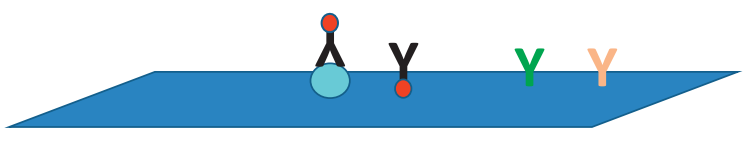

(b)

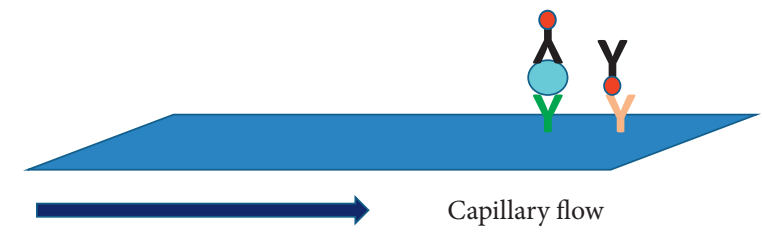

(c)

FIgURE 1: General principle of an LFT immunoassay. (a) Sample with an analyte (circle) is added to the pad where a labeled antibody (Y shaped) already exists. (b) Analyte and a labeled antibody are carried by a lateral flow (arrow) and they can mutually interact. (c) Complex of analyte-labeled antibody and the labeled antibody are captured on test spot (analyte) or control spot (unreacted antibody) forming colored lines.

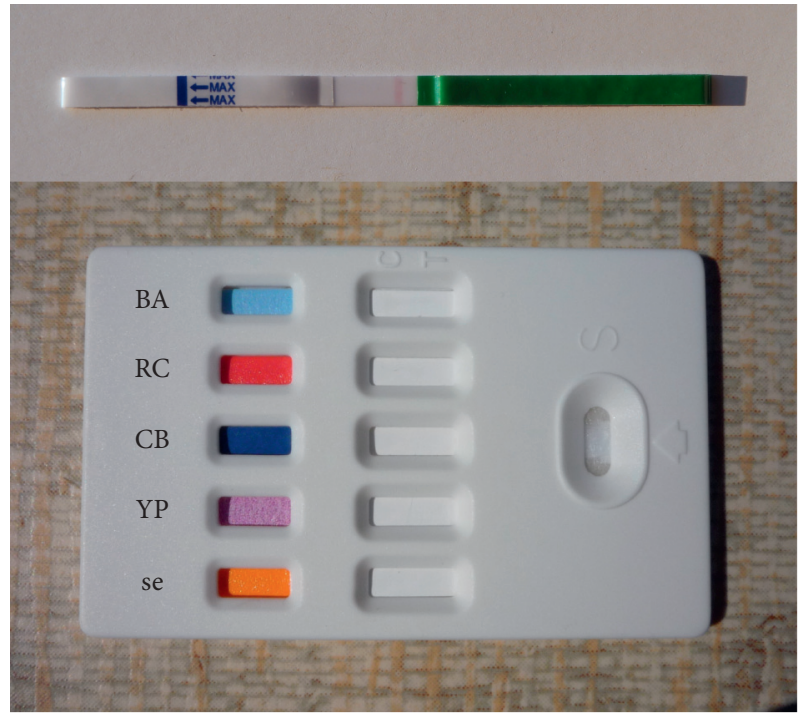

Figure 2: Appearance of commercial LFT devices. In the upper part, there is LFT for human chorionic gonadotropin; in the down part, there is a photograph of LFT for the contemporary determination of five biological warfare agents Bacillus anthracis, ricin, Clostridium botulinum/botulinum toxin, Yersinia pestis, and staphylococcal enterotoxin B by Pro Strips (Advnt Biotechnologies, Phoenix, AZ, USA).

was developed by Liu and coworkers for assay of dinitolmide in chicken tissue [40]. The researchers reported a limit of detection of $2.5 \mu \mathrm{g} / \mathrm{kg}$ for chicken tissue containing dinitolmide, and the assay was fully comparable to liquid chromatography and ELISA. Gold nanoparticles (gold spheres with size 30 and $100 \mathrm{~nm}$ or gold-silica shells with size $150 \mathrm{~nm}$ ) and antibody-based detection were also used in the development of an LFT for the human immunodeficiency virus [41]. The gold nanoparticles were covered by a monoclonal antibody against protein p24 of the human immunodeficiency virus, and the whole assay was made in a standard manner. Signal was recorded by thermal contrast reading using an IR camera and laser. The assay was highly sensitive as a limit of detection of $8 \mathrm{pg} / \mathrm{ml}$ of p24 was achieved.
The relevance of LFT can be largely perceived in the recent events when a fast test for the diagnosis of COVID-19 was demanded. The standard diagnosis of COVID-19 was based on the polymerase chain reaction (presence of pathogen) and ELISA (prove of antibodies), but the tests have to be performed in specialized laboratories, and they require a quite long time to be finished. LFTs were successfully introduced as an alternative to the polymerase chain reaction and ELISA, and they were proved to be suitable for routine diagnosis based on the detection of COVID-19 antigen. Though they are not a replacement of polymerase chain reaction and ELISA, they were proved to be a suitable tool to be developed in a short period and used wherever necessary.

Concurrently, the recognition capability of antibodies suitable for antigens measuring respective antigens when antibodies are assayed is frequently replaced by the use of aptamers by many assays. Extensive progress in aptamer preparation has been reached in recent years, and the aptamers typically comprise ribonucleic acid (RNA), deoxyribonucleic acid (DNA), peptides, or proteins [42-48]. Their potency for LFT development was recognized as well [49]. Aptamers found their way to the construction of LFT, and they have become a relevant recognition molecule in LFT devices' development. In a work by Tripathi and coworkers, the LFT test was constructed for the point-of-care cancer diagnosis by the measurement of marker CA125 level [50]. The researchers used aptamer linked with gold nanoparticles serving as peroxidase mimetic and optimized the assay for the detection of CA125 in human serum. The assay had a limit of detection of $3.71 \mathrm{U} / \mathrm{ml}$ and correlated with ELISA. A DNA aptamer for residual penicillin antibiotic ampicillin was prepared by Lin and coworkers [51]. The researchers used hexachlorofluorescein for oligonucleotide labeling and were able to detect ampicillin in a range of 10 to $200 \mathrm{ng} / \mathrm{l}$ and a limit of quantification of $2.71 \mathrm{ng} / \mathrm{l}$ when water sample was analyzed. DNA aptamer was also used for the detection of dopamine in urine [52]. In this study, dopamine duplex DNA aptamers were conjugated to $40 \mathrm{~nm}$ gold nanoparticles, and LFT was performed in a standard manner resulting in a limit of detection of $50 \mathrm{ng} / \mathrm{ml}$. Protein 
osteopontin representing a new marker for cancer was detected by a biotinylated aptamer and then streptavidin modified gold nanoparticles served for the visualization purpose [53]. The assay had a limit of detection of $0.1 \mathrm{ng} / \mathrm{ml}$ with dynamic detection of osteopontin in a range from 10 to $500 \mathrm{ng} / \mathrm{ml}$ for a measuring time of 5 minutes. Aptamer-based LFT was chosen by Ali and coworkers for the early diagnosis of type-2 diabetes by assay of protein vaspin using fluorescent upconverting nanoparticles [54]. Vaspin was recognized in a range of $0.1-55 \mathrm{ng} / \mathrm{ml}$ with a limit of detection of $39 \mathrm{pg} / \mathrm{ml}$. LFT does not have to be targeted on defined molecules only. In a work by $\mathrm{Yu}$ and coworkers, LFT was developed for tumor-derived exosomes for rapid diagnosis of lung cell cancer [55]. Aptamer specific to CD63 on exosome surface and gold nanoparticles giving good visualization and observability of the assay by a naked eye were used for the LFT construction. The assay was proved on exosomes isolated from human lung carcinoma cells in a dilution of $6.4 \times 10^{9}$ particles/ml. Quantum dots are another material that can serve for the purpose of reaction visualization and macromolecules labeling [56-59]. An LFT method based on CdTe quantum dots was, for instance, constructed by $\mathrm{Lu}$ and coworkers in order to detect Shiga toxin type II [60]. The authors also worked with gold nanoparticles as a material for labeling antibodies. While labeling by quantum dots provided a limit of detection of $25 \mathrm{ng} / \mathrm{ml}$, the LFT based on CdTe quantum dots had a five times lower limit of detection: $5 \mathrm{ng} /$ $\mathrm{ml}$. The LFT tests can be improved by connecting with other techniques improving samples and sensitivity increased. For instance, detection of Escherichia coli O157:H7 was performed in two steps: the first step was based on bacterium captured by immunomagnetic nanoparticles and monoclonal antibody conjugate with beta-lactamase and gold nanoparticles; the second step contained penicillin solution application and hydrolysis by the beta-lactamase [61]. The final test containing LFT consisted of an ultrasensitive penicillin immunochromatographic test strip. The assay had a limit of detection of $137 \mathrm{CFU} / \mathrm{ml}$. Further investigation is also focused on other types of recognition parts and labels like molecularly imprinted polymers [62] and the use of liposome enhanced signal amplification [63]. Highly fluorescent europium chelate loaded silica nanoparticles can be mentioned as another type of label [64]. Research on matrix composition is also demanded, and it can improve analytical properties. Nitrocellulose or nitrocellulose coated with nanocolloids appears to be promising $[40,65]$. An overview of the aforementioned LFTs is given in Table 1 .

Considering the current trends, it is clear that the new directions in LFT research are focused on two major areas. Firstly, new recognition elements are researched. Secondly, new types of nanoparticles are used for LFT construction. All the new materials can improve the final analytical parameters of a final LFT, but the suitability of the particular materials will depend on the type of assay and other conditions. There probably will never be an ideal recognition element or a label for any assay scenarios. Molecularly imprinted polymers and aptamers can be prospective recognition elements, but antibodies will probably remain an irreplaceable part of many commercial LFTs. Standard chemical labels like fluorescein will also remain a part of standard LFTs though nanoparticles like the gold one or quantum dots will probably represent a better alternative gaining higher popularity in the future praxis.

Considering the current options in analytical chemistry, LFT remains probably the major tool for point-of-care specific diagnosis of various pathologies besides the devices like Clark glucose biosensor and simple urine colorimetric test strips. Compared to the other tests, LFT has quite high versatility for the diagnosis of good presumptions to be used under point-of-care conditions; on the other hand, LFT has a limitation on the molecular weight of analyte because the assay is on an affinity principle. Analytes with low molecular weight are not suitable for a standard immunoassay, and a competitive format is the only possibility of how to use an immunoassay for the analysis of a small compound. However, the new types of recognition elements like aptamers bring improvement and even LFT for small molecules like dinitolmide, ampicillin, and dopamine can be seen in the examples of new research on LFT.

2.2. Instrumentation of LFT for Point-of-Care Diagnosis. LFT methods are typically intended to be either qualitative or semiquantitative, and the coloration is determined by a naked eye. If the assay is performed as a semiquantitative, the found range of value is highly inaccurate. The overall simplicity of the method and no necessity to use an analytical device, electricity, or elaborative sample manipulation are the major advantages of LFT. On the other hand, there are disadvantages as well. The scaling of coloration by a naked eye is highly subjective and also depends on ambient light conditions. The subjective perception of color may be a problem when the point-of-care diagnosis is performed by elderly or disabled people. Development of coloration readers suitable for standard LFT is a way of how to improve the assay. The reader devices are especially desired in pointof-care testing [66]. The improved LFT assays are quantitative or at least semiquantitative with acceptable accuracy of concentration range determination.

In the current time, broad attention is given to digital photography because of the good availability of cameras and their integration into smartphones. Standard cameras integrated into smartphones are able to provide at least 8-bit digital photography in a format like jpg and have information about color depth for the 8-bit photography equal to 256 variables for each channel. Better cameras giving figures in $12,14,16$, and more bits and providing raw data from the digital sensor are also widely available in the market. Digital photography is highly suitable for colorimetry by color depth analysis and colorimetric tests performed on a thinlayer-like paper-based assays and detector strips like the $\mathrm{pH}$ and others can be recorded this way, and the digital photography-assisted assay is well suitable for point-of-care testing [7, 36, 67-69]. Digital photography has also its limitations making the assay inaccurate under some conditions. In the first point, the light source has to be mentioned. The light conditions are crucial when a sensor is photographed; integrated light-emitting diodes can have problems with the light temperature setting. There can be 
TABLE 1: Overview of LFT in point-of-care diagnosis.

\begin{tabular}{|c|c|c|c|c|}
\hline $\begin{array}{l}\text { Assay/diagnosis of a } \\
\text { pathology }\end{array}$ & Type of recognition part & $\begin{array}{c}\text { Type of label attached to the } \\
\text { recognition part }\end{array}$ & Analytical specifications & Reference \\
\hline COVID-19 & Antibody & Colloidal gold & $\begin{array}{l}\text { Full correlation with ELISA for clinical } \\
\text { samples testing }\end{array}$ & {$[37]$} \\
\hline $\begin{array}{l}\text { COVID-19-specific } \\
\text { antibodies recognition }\end{array}$ & $\begin{array}{c}\text { SARS-CoV-2 } \\
\text { nucleoproteins }\end{array}$ & Selenium nanoparticles & $\begin{array}{l}20 \mathrm{ng} / \mathrm{ml} \text { for IgM and } 5 \mathrm{ng} / \mathrm{ml} \text { for IgG } \\
\text { in } 10 \text { minutes }\end{array}$ & {$[38]$} \\
\hline Mycoplasma & p48 protein & Carbon nanoparticles & $\begin{array}{l}\text { 100\% specificity, no cross-reactivity, } \\
\text { full correlation with ELISA }\end{array}$ & [39] \\
\hline Dinitolmide in tissue & Monoclonal antibody & Gold nanoparticles & $\begin{array}{l}\text { Limit of detection of } 2.5 \mu \mathrm{g} / \mathrm{kg} \text { for } \\
\text { chicken tissue containing dinitolmide }\end{array}$ & {$[40]$} \\
\hline $\begin{array}{l}\text { Protein p24 of human } \\
\text { immunodeficiency virus }\end{array}$ & Monoclonal antibody & Gold nanoparticles & Limit of detection of $8 \mathrm{pg} / \mathrm{ml}$ & {$[41]$} \\
\hline $\begin{array}{l}\text { Diagnosis of cancer by } \\
\text { CA125 assay }\end{array}$ & Aptamer & Gold nanoparticles & Limit of detection of $3.71 \mathrm{U} / \mathrm{ml}$ & {$[50]$} \\
\hline Ampicillin in water & DNA aptamer & Hexachlorofluorescein & Limit of quantification of $2.71 \mathrm{ng} / \mathrm{l}$ & [51] \\
\hline Dopamine in urine & DNA aptamer & Gold nanoparticles & Limit of detection of $50 \mathrm{ng} / \mathrm{ml}$ & [52] \\
\hline Cancer marker osteopontin & Biotinylated aptamer & $\begin{array}{l}\text { Conjugate streptavidin-gold } \\
\text { nanoparticles }\end{array}$ & $\begin{array}{l}\text { Limit of detection } 0.1 \mathrm{ng} / \mathrm{ml} \text {, with a } \\
\text { dynamic range of } 10 \text { to } 500 \mathrm{ng} / \mathrm{ml} \text {, } \\
\text { time per assay } 5 \text { minutes }\end{array}$ & {$[53]$} \\
\hline $\begin{array}{l}\text { Assay of vaspin as an early } \\
\text { marker of type- } 2 \text { diabetes }\end{array}$ & Aptamer & $\begin{array}{c}\text { Fluorescent upconverting } \\
\text { nanoparticles }\end{array}$ & $\begin{array}{l}\text { Limit of detection for vaspin of } 39 \mathrm{pg} / \\
\mathrm{ml}\end{array}$ & {$[54]$} \\
\hline $\begin{array}{l}\text { Exosomes for rapid diagnosis } \\
\text { of lung cell cancer }\end{array}$ & $\begin{array}{l}\text { Aptamer specific to } \\
\text { CD63 on exosomes } \\
\text { surface }\end{array}$ & Gold nanoparticles & Detection of $6.4 \times 10^{9}$ exosomes $/ \mathrm{ml}$ & {$[55]$} \\
\hline Shiga toxin type II & Antibodies & $\begin{array}{l}\text { Gold nanoparticles and CdSe } \\
\text { quantum dots }\end{array}$ & $\begin{array}{c}25 \mathrm{ng} / \mathrm{ml} \text { (labeling by gold } \\
\text { nanoparticles), } 5 \mathrm{ng} / \mathrm{ml} \text { (labeling by } \\
\text { quantum dots) }\end{array}$ & {$[60]$} \\
\hline
\end{tabular}

also problems with the setting of white balance and color temperature in the camera. Problems with lens quality can also play a role when a cheap camera is used for point-ofcare testing. Nevertheless, the use of digital cameras in personal diagnosis is considered as the next direction of research and application into praxis [70-75].

Instrumental analysis of spots formed in LFT was introduced in several applications. In the aforementioned study by Zhan and coworkers, detection of $\mathrm{p} 24$ protein of the human immunodeficiency virus was made using thermal contrast reading [41]. The spot on LFT was formed by a complex of gold nanoparticle conjugate with p24 from a sample and capturing zone on the LFT pad. The spot was focused by laser with wavelength 532 or $800 \mathrm{~nm}$ with power adjusted in the range from 10 to $500 \mathrm{~mW}$. The alighted spot was recorded, and temperature measured by an IR camera and digital data for further processing and signal scaling were recorded. Digital camera containing complementary metal-oxide-semiconductor (CMOS) chip served for the spot color recording in the study by Jahanpeyma and coworkers [76]. The researchers tested their LFT device for the hybridization of DNA, and visualization was made by the application of a biotinylated detector probe in the presence of peroxidase-streptavidin conjugate. Just the peroxidase was responsible for the chemiluminescence reaction recorded by a camera. The assay was tested for proving the 16S rRNA gene from Escherichia coli, and the lowest reached limit of detection was equal to $1.5 \mathrm{pmol} / \mathrm{l}$. The use of peroxidase-catalyzed reaction in an LFT was also described in a paper by Mirasoli and coworkers [77]. They adopted their method for the detection of fumonisin in food samples, and the mycotoxin was detected in a range of $2.5-500 \mu \mathrm{g} / 1$ with a limit of detection of $2.5 \mu \mathrm{g} / \mathrm{l}$ for an assay lasting for 25 minutes. The detection signal was evaluated by a chargecouple device (CCD) camera. The authors stated that the peroxidase reaction generating chemiluminescence products is more suitable for quantitative LFT assay than an assay where colloidal gold is used instead of peroxidase. The digital scaling of coloration can be even made by simpler devices than cameras. Digital scanner was selected as an analytical tool in the work by Posthuma-Trumpie and coworkers [78]. The authors successfully performed a standard LFT test for progesterone assay using antibodies and carbon colloid as a label and the LFT strips scanned and analyzed digitally. Spots on an LFT test can be evaluated, and coloration was determined by a smartphone camera which makes the assays more available to most people. A smartphone camera assay based on an LFT was investigated for the detection of mercury [79]. The assay comprised of the use of streptavidinbiotinylated DNA probes modified with gold nanoparticles and adsorbing mercury was proved with a limit of detection of $2.53 \mathrm{nmol} / \mathrm{l}$. In another smartphone application, uricemia (uric acid content in the blood) was measured by a combination of an LFT where coloration was initiated Prussian blue nanoparticles as artificial nanozymes and standard smartphone for spots characterization [80]. The assay 
TABLE 2: LFT signal recording by an analytical instrument.

\begin{tabular}{|c|c|c|c|}
\hline Type of assay & Type of instrumentation & $\begin{array}{l}\text { Physical principle of the instrumental } \\
\text { assay }\end{array}$ & Reference \\
\hline $\begin{array}{l}\text { LFT for p24 protein from human } \\
\text { immunodeficiency virus, gold nanoparticles } \\
\text { conjugated with a monoclonal antibody against p24 } \\
\text { were used }\end{array}$ & $\begin{array}{l}\text { Laser alighting specific spots, } \\
\text { IR camera visually recording } \\
\text { temperature }\end{array}$ & Thermal contrast reading & {$[41]$} \\
\hline $\begin{array}{l}\text { Detection of 16S rRNA gene from Escherichia coli } \\
\text { by hybridization and use of biotinylated probe and } \\
\text { peroxidase conjugated with streptavidin, } \\
\text { peroxidase was responsible for the } \\
\text { chemiluminescent reaction }\end{array}$ & $\begin{array}{l}\text { Digital camera with CMOS } \\
\text { chip }\end{array}$ & $\begin{array}{l}\text { Digital camera recorded } \\
\text { chemiluminescence provided by } \\
\text { peroxidase }\end{array}$ & {$[76]$} \\
\hline $\begin{array}{l}\text { Detection of fumonisin, labeling of antibodies by } \\
\text { peroxidase allows performing chemiluminescent } \\
\text { chemical reaction that is instrumentally measured }\end{array}$ & Digital camera with CCD chip & $\begin{array}{c}\text { Digital camera recorded } \\
\text { chemiluminescence provided by } \\
\text { peroxidase }\end{array}$ & {$[77]$} \\
\hline $\begin{array}{l}\text { LFT immunoassay of progesterone based on } \\
\text { labeling by carbon colloid }\end{array}$ & Digital scanner & $\begin{array}{c}\text { Strips were scanned and digital data } \\
\text { analyzed }\end{array}$ & {$[78]$} \\
\hline $\begin{array}{l}\text { The LFT assay comprised of the use of streptavidin- } \\
\text { biotinylated DNA probes modified with gold } \\
\text { nanoparticles }\end{array}$ & Smartphone camera & $\begin{array}{c}\text { Detected spots were photographed by a } \\
\text { smartphone camera, and coloration was } \\
\text { measured }\end{array}$ & {$[79]$} \\
\hline $\begin{array}{l}\text { LFT where coloration was initiated Prussian blue } \\
\text { nanoparticles as artificial nanozymes }\end{array}$ & Smartphone camera & $\begin{array}{c}\text { Detected spots were photographed by a } \\
\text { smartphone camera, and coloration was } \\
\text { measured }\end{array}$ & {$[80]$} \\
\hline
\end{tabular}

exerted a linear range of $1.5-8.5 \mathrm{mg} / \mathrm{dl}$ for uric acid. An overview of the types of instrumentation applicable for an LFT assay is shown in Table 2.

\section{Conclusions}

LFT devices and kits can be found in the current market as standard devices, and new improved types are researched. Three major directions of improvement can be observed when the current research is compared with the traditional LFT devices on immunoassay principle: (1) new labels and materials including nanoparticles providing contrast coloration, (2) new recognition molecules selectively interacting with analytes, and (3) types of instrumentation making the LFT-based assays quantitative from the originally qualitative one. All the facts make the LFT a significant tool in point-of-care diagnostic where it can be performed for multiple diagnoses or analyses of harmful substances or microorganisms. Overall simplicity and growing sensitivity allow making LFT a tool for a wide number of markers. Though the traditional analytes in an LFT assay were molecules with higher molecular weight, it is expected that the LFT will become a universal tool even for analytes with lower molecular weight and make the assay more universal. The relevance of LFT was also evident during the COVID-19 crisis when the tests COVID antibodies and antigens were urgently developed and marketed in a quite short time.

\section{Data Availability}

No data were used to support this study.

\section{Conflicts of Interest}

The authors declare that they have no conflicts of interest.

\section{Acknowledgments}

This work was supported by a long-term organization development plan "Medical Aspects of Weapons of Mass Destruction" (Faculty of Military Health Sciences, University of Defense, Czech Republic) and Technological Agency od Czech Republic (TACR) (TH03030336).

\section{References}

[1] P. Babaie, A. Saadati, and M. Hasanzadeh, "Recent progress and challenges on the bioassay of pathogenic bacteria," Journal of Biomedical Materials Research Part B: Applied Biomaterials, vol. 14, Article ID 34723, 2020.

[2] S. Menon, M. R. Mathew, S. Sam, K. Keerthi, and K. G. Kumar, "Recent advances and challenges in electrochemical biosensors for emerging and re-emerging infectious diseases," Journal of Electroanalytical Chemistry, vol. 878, Article ID 114596, 2020.

[3] Q. H. Nguyen and M. I. Kim, "Nanomaterial-mediated paperbased biosensors for colorimetric pathogen detection," TrAC Trends in Analytical Chemistry, vol. 132, Article ID 116038, 2020.

[4] M. Pohanka, "The piezoelectric biosensors: principles and applications, a review," International Journal of Electrochemical Science, vol. 12, pp. 496-506, 2017.

[5] B. Senf, W.-H. Yeo, and J.-H. Kim, "Recent advances in portable biosensors for biomarker detection in body fluids," Biosensors, vol. 10, no. 9, p. 127, 2020.

[6] S.-u. Hassan, A. Tariq, Z. Noreen et al., "Capillary-driven flow microfluidics combined with smartphone detection: an emerging tool for point-of-care diagnostics," Diagnostics, vol. 10, no. 8, p. 509, 2020.

[7] D. S. Y. Ong and M. Poljak, "Smartphones as mobile microbiological laboratories," Clinical Microbiology and Infection, vol. 26, no. 4, pp. 421-424, 2020. 
[8] M. Pohanka, "Small camera as a handheld colorimetric tool in the analytical chemistry," Chemical Papers, vol. 71, no. 9, pp. 1553-1561, 2017c.

[9] H. A. Watson, R. M. Tribe, and A. H. Shennan, "The role of medical smartphone apps in clinical decision-support: a literature review," Artificial Intelligence in Medicine, vol. 100, Article ID 101707, 2019.

[10] N. A. Izmailov and M. S. Schraiber, "Spot chromatographic adsorption analysis and its application in pharmacy," Communication I Farmatsiya, vol. 3, pp. 1-7, 1936.

[11] F. Klein and M. B. Janssens, "Standardisation of serological tests for rheumatoid factor measurement," Annals of the Rheumatic Diseases, vol. 46, no. 9, pp. 674-680, 1987.

[12] J. M. Singer, S. C. Edberg, R. L. Markowitz, J. D. Glickman, L. Miller, and R. Marchitelli, "Performance of latex-fixation kits used for serologic diagnosis of rheumatoid factor in rheumatoid arthritis sera," American Journal of Clinical Pathology, vol. 72, no. 4, pp. 597-603, 1979.

[13] A. E. Urusov, A. V. Zherdev, and B. B. Dzantiev, "Towards lateral flow quantitative assays: detection approaches," Biosensors, vol. 9, no. 3, p. 89, 2019.

[14] B. O'Farrell, "Lateral flow technology for field-based applications-basics and advanced developments," Topics in Companion Animal Medicine, vol. 30, no. 4, pp. 139-147, 2015.

[15] A. Chen and S. Yang, "Replacing antibodies with aptamers in lateral flow immunoassay," Biosensors and Bioelectronics, vol. 71, pp. 230-242, 2015.

[16] Y. Zhang, X. Liu, L. Wang et al., "Improvement in detection limit for lateral flow assay of biomacromolecules by test-zone pre-enrichment," Scientific Reports, vol. 10, no. 1, p. 9604 , 2020.

[17] S. D. Lawn, "Point-of-care detection of lipoarabinomannan (LAM) in urine for diagnosis of HIV-associated tuberculosis: a state of the art review," BMC Infectious Diseases, vol. 12, no. 1, pp. 1471-2334, 2012.

[18] M. Shah, C. Hanrahan, Z. Y. Wang et al., "Lateral flow urine lipoarabinomannan assay for detecting active tuberculosis in HIV-positive adults," Cochrane Database of Systematic Reviews, vol. 10, p. CD011420, 2016.

[19] E. S. Hunter, I. D. Page, M. D. Richardson, and D. W. Denning, "Evaluation of the LDBio Aspergillus ICT lateral flow assay for serodiagnosis of allergic bronchopulmonary aspergillosis," PLoS One, vol. 15, 2020.

[20] P. Schubert-Ullrich, J. Rudolf, P. Ansari et al., "Commercialized rapid immunoanalytical tests for determination of allergenic food proteins: an overview," Analytical and Bioanalytical Chemistry, vol. 395, no. 1, pp. 69-81, 2009.

[21] M. Röder, S. Vieths, and T. Holzhauser, "Commercial lateral flow devices for rapid detection of peanut (Arachis hypogaea) and hazelnut (Corylus avellana) cross-contamination in the industrial production of cookies," Analytical and Bioanalytical Chemistry, vol. 395, no. 1, pp. 103-109, 2009.

[22] F. Cui and H. S. Zhou, "Diagnostic methods and potential portable biosensors for coronavirus disease 2019," Biosensors and Bioelectronics, vol. 165, Article ID 112349, 2020.

[23] H. A. Hussein, R. Y. A. Hassan, M. Chino, and F. Febbraio, "Point-of-Care diagnostics of COVID-19: from current work to future perspectives," Sensors, vol. 20, no. 15, p. 4289, 2020.

[24] Z. Lyu, M. Harada Sassa, T. Fujitani, and K. H. Harada, "Serological tests for SARS-CoV-2 coronavirus by commercially available point-of-care and laboratory diagnostics in pre-COVID-19 samples in Japan," Diseases, vol. 8, no. 4, p. 36, 2020 .
[25] L. Weidner, S. Gänsdorfer, S. Unterweger et al., "Quantification of SARS-CoV-2 antibodies with eight commercially available immunoassays," Journal of Clinical Virology, vol. 129, Article ID 104540, 2020.

[26] D. M. Pfukenyi, E. Meletis, B. Modise et al., "Evaluation of the sensitivity and specificity of the lateral flow assay, Rose Bengal test and the complement fixation test for the diagnosis of brucellosis in cattle using Bayesian latent class analysis," Preventive Veterinary Medicine, vol. 181, Article ID 105075, 2020.

[27] S. Halecker, S. Joseph, R. Mohammed et al., "Comparative evaluation of different antigen detection methods for the detection of peste des petits ruminants virus," Transboundary and Emerging Diseases, vol. 5, Article ID 13660, 2020.

[28] J. C. Wei, Y. M. Gao, G. Q. Li et al., "A lateral flow immunochromatographic assay (LFIA) strip reader based on scheduler and 8051 IP core," Automatika, vol. 57, no. 4, pp. 1079-1088, 2016.

[29] F. Gessler, S. Pagel-Wieder, M.-A. Avondet, and H. Böhnel, "Evaluation of lateral flow assays for the detection of botulinum neurotoxin type A and their application in laboratory diagnosis of botulism," Diagnostic Microbiology and Infectious Disease, vol. 57, no. 3, pp. 243-249, 2007.

[30] H.-L. Hsu, C.-C. Chuang, C.-C. Liang et al., "Rapid and sensitive detection of Yersinia pestis by lateral-flow assay in simulated clinical samples," BMC Infectious Diseases, vol. 18, no. 1, p. 402, 2018.

[31] M. Pohanka, "Current trends in the biosensors for biological warfare agents assay," Materials, vol. 12, no. 14, p. 2303, 2019.

[32] I. Ziegler, P. Vollmar, M. Knüpfer, P. Braun, and K. Stoecker, "Reevaluating limits of detection of 12 lateral flow immunoassays for the detection of Yersinia pestis, Francisella tularensis, and Bacillus anthracis spores using viable risk group-3 strains," Journal of Applied Microbiology, 2020.

[33] E. Frantz, H. Li, and A. J. Steckl, "Quantitative hematocrit measurement of whole blood in a point-of-care lateral flow device using a smartphone flow tracking app," Biosensors and Bioelectronics, vol. 163, Article ID 112300, 2020.

[34] Y. Jung, Y. Heo, J. J. Lee, A. Deering, and E. Bae, "Smartphone-based lateral flow imaging system for detection of food-borne bacteria E.coli O157:H7," Journal of Microbiological Methods, vol. 168, Article ID 105800, 2020.

[35] M. Pohanka, "Photography by cameras integrated in smartphones as a tool for analytical chemistry represented by an butyrylcholinesterase activity assay," Sensors, vol. 15, no. 6, pp. 13752-13762, 2015.

[36] M. Pohanka, "Colorimetric hand-held sensors and biosensors with a small digital camera as signal recorder, a review," Reviews in Analytical Chemistry, vol. 39, no. 1, p. 20, 2020.

[37] S. Pickering, G. Betancor, R. P. Galão et al., "Comparative assessment of multiple COVID-19 serological technologies supports continued evaluation of point-of-care lateral flow assays in hospital and community healthcare settings," PLOS Pathogens, vol. 16, no. 9, Article ID e1008817, 2020.

[38] Z. Wang, Z. Zheng, H. Hu et al., "A point-of-care selenium nanoparticle-based test for the combined detection of antiSARS-CoV-2 IgM and IgG in human serum and blood," Lab on a Chip, vol. 20, no. 22, p. 4255, 2020.

[39] F. Shi, Y. Zhao, Y. Sun, and C. Chen, "Development and application of a colloidal carbon test strip for the detection of antibodies against Mycoplasma bovis," World Journal of Microbiology and Biotechnology, vol. 36, no. 10, p. 157, 2020.

[40] C. Liu, S. Fang, Y. Tian et al., "Rapid detection of Escherichia coli O157:H7 in milk, bread, and jelly by lac dye coloration- 
based bidirectional lateral flow immunoassay strip," Journal of Food Safety, 2020.

[41] L. Zhan, T. Granade, Y. Liu et al., "Development and optimization of thermal contrast amplification lateral flow immunoassays for ultrasensitive HIV p24 protein detection," Microsystems \& Nanoengineering, vol. 6, no. 1, p. 54, 2020.

[42] F. Farshchi and M. Hasanzadeh, "Nanomaterial based aptasensing of prostate specific antigen (PSA): recent progress and challenges in efficient diagnosis of prostate cancer using biomedicine," Biomedicine \& Pharmacotherapy, vol. 132, Article ID 110878, 2020.

[43] Y. Guo, F. Yang, Y. Yao et al., "Novel Au-tetrahedral aptamer nanostructure for the electrochemiluminescence detection of acetamiprid," Journal of Hazardous Materials, vol. 401, Article ID 123794, 2021.

[44] N. Cheng, Y. Liu, O. Mukama et al., "A signal-enhanced and sensitive lateral flow aptasensor for the rapid detection of PDGF-BB,” RSC Advances, vol. 10, no. 32, pp. 18601-18607, 2020.

[45] T. N. Navien, R. Thevendran, H. Y. Hamdani, T.-H. Tang, and M. Citartan, "In silico molecular docking in DNA aptamer development," Biochimie, vol. 180, pp. 54-67, 2021.

[46] Y. Ning, J. Hu, and F. Lu, "Aptamers used for biosensors and targeted therapy," Biomedicine \& Pharmacotherapy, vol. 132, Article ID 110902, 2020.

[47] F. Xue, Y. Chen, Y. Wen et al., "Isolation of extracellular vesicles with multivalent aptamers," The Analyst, vol. 146, no. 1, p. 253, 2020.

[48] T. Yang, X. Yang, X. Guo et al., “A novel fluorometric aptasensor based on carbon nanocomposite for sensitive detection of Escherichia coli O157:H7 in milk," Journal of Dairy Science, vol. 103, no. 9, pp. 7879-7889, 2020.

[49] R. Reid, B. Chatterjee, S. J. Das, S. Ghosh, and T. K. Sharma, "Application of aptamers as molecular recognition elements in lateral flow assays," Analytical Biochemistry, vol. 593, Article ID 113574, 2020.

[50] P. Tripathi, A. Kumar, M. Sachan, S. Gupta, and S. Nara, "Aptamer-gold nanozyme based competitive lateral flow assay for rapid detection of CA125 in human serum," Biosensors and Bioelectronics, vol. 165, Article ID 112368, 2020.

[51] H. Lin, F. Fang, J. Zang et al., "A fluorescent sensor-assisted paper-based competitive lateral flow immunoassay for the rapid and sensitive detection of ampicillin in hospital wastewater," Micromachines, vol. 11, no. 4, p. 431, 2020.

[52] S. Dalirirad and A. J. Steckl, "Lateral flow assay using aptamerbased sensing for on-site detection of dopamine in urine," Analytical Biochemistry, vol. 596, Article ID 113637, 2020.

[53] O. Mukama, W. Wu, J. Wu et al., "A highly sensitive and specific lateral flow aptasensor for the detection of human osteopontin," Talanta, vol. 210, Article ID 120624, 2020.

[54] M. Ali, M. Sajid, M. A. U. Khalid et al., "A fluorescent lateral flow biosensor for the quantitative detection of Vaspin using upconverting nanoparticles," Spectrochimica Acta Part A: Molecular and Biomolecular Spectroscopy, vol. 226, Article ID 117610, 2020.

[55] Q. Yu, Q. Zhao, S. Wang et al., "Development of a lateral flow aptamer assay strip for facile identification of theranostic exosomes isolated from human lung carcinoma cells," Analytical Biochemistry, vol. 594, Article ID 113591, 2020.

[56] J. Cao, B. Zhu, K. Zheng et al., "Recent progress in NIR-II contrast agent for biological imaging," Frontiers in Bioengineering and Biotechnology, vol. 7, p. 487, 2020.
[57] M. Ganesan and P. Nagaraaj, "Quantum dots as nanosensors for detection of toxics: a literature review," Analytical Methods, vol. 12, no. 35, pp. 4254-4275, 2020.

[58] M. Pan, X. Xie, K. Liu, J. Yang, L. Hong, and S. Wang, "Fluorescent carbon quantum dots-synthesis, functionalization and sensing application in food analysis," Nanomaterials, vol. 10, no. 5, p. 930, 2020.

[59] M. Pohanka, "Quantum dots in the therapy: current trends and perspectives," Mini Rev Med Chem, vol. 20, p. 20, 2017.

[60] T. Lu, K.-D. Zhu, C. Huang et al., "Rapid detection of Shiga toxin type II using lateral flow immunochromatography test strips of colorimetry and fluorimetry," The Analyst, vol. 145, no. 1, pp. 76-82, 2020.

[61] W. Chen, S. Shan, J. Peng et al., "Sensitive and hook effect-free lateral flow assay integrated with cascade signal transduction system," Sensors and Actuators B: Chemical, vol. 321, Article ID 128465, 2020.

[62] Y. He, S. Hong, M. Wang et al., "Development of fluorescent lateral flow test strips based on an electrospun molecularly imprinted membrane for detection of triazophos residues in tap water," New Journal of Chemistry, vol. 44, no. 15, pp. 6026-6036, 2020.

[63] S. Kim and H. D. Sikes, "Liposome-enhanced polymerizationbased signal amplification for highly sensitive naked-eye biodetection in paper-based sensors," ACS Applied Materials \& Interfaces, vol. 11, no. 31, pp. 28469-28477, 2019.

[64] X. Xia, Y. Xu, X. Zhao, and Q. Li, "Lateral flow immunoassay using europium chelate-loaded silica nanoparticles as labels," Clinical Chemistry, vol. 55, no. 1, pp. 179-182, 2009.

[65] P. Manta, R. Nagraik, A. Sharma et al., "Optical density optimization of malaria Pan rapid diagnostic test strips for improved test zone band intensity," Diagnostics, vol. 10, no. 11 , p. $880,2020$.

[66] R. Xiao, L. Lu, Z. Rong et al., "Portable and multiplexed lateral flow immunoassay reader based on SERS for highly sensitive point-of-care testing," Biosensors and Bioelectronics, vol. 168, Article ID 112524, 2020.

[67] G. M. Fernandes, W. R. Silva, D. N. Barreto et al., "Novel approaches for colorimetric measurements in analytical chemistry - a review," Analytica Chimica Acta, vol. 1135, pp. 187-203, 2020.

[68] H. Chen, Z. Li, L. Zhang, P. Sawaya, J. Shi, and P. Wang, "Quantitation of femtomolar-level protein biomarkers using a simple microbubbling digital assay and bright-field smartphone imaging," Angewandte Chemie International Edition, vol. 58, no. 39, pp. 13922-13928, 2019.

[69] M. Pohanka, J. Zakova, and I. Sedlacek, "Digital camera-based lipase biosensor for the determination of paraoxon," Sensors and Actuators B: Chemical, vol. 273, pp. 610-615, 2018.

[70] L. Harendarcikova and J. Petr, "Smartphones \& microfluidics: marriage for the future," Electrophoresis, vol. 39, pp. 13191328, 2018.

[71] I. Nishidate, M. Minakawa, D. McDuff et al., "Simple and affordable imaging of multiple physiological parameters with RGB camera-based diffuse reflectance spectroscopy," Biomedical Optics Express, vol. 11, no. 2, pp. 1073-1091, 2020.

[72] D. Quesada-González and A. Merkoçi, "Mobile phone-based biosensing: an emerging "diagnostic and communication" technology," Biosensors and Bioelectronics, vol. 92, pp. 549$562,2017$.

[73] T. Sergeyeva, D. Yarynka, L. Dubey et al., "Sensor based on molecularly imprinted polymer membranes and smartphone for detection of Fusarium contamination in cereals," Sensors, vol. 20, no. 15, p. 4304, 2020. 
[74] K. Tomimuro, K. Tenda, Y. Ni, Y. Hiruta, M. Merkx, and D. Citterio, "Thread-based bioluminescent sensor for detecting multiple antibodies in a single drop of whole blood," ACS Sensors, vol. 5, no. 6, pp. 1786-1794, 2020.

[75] A. K. Yetisen, M. S. Akram, and C. R. Lowe, "Paper-based microfluidic point-of-care diagnostic devices," Lab on a Chip, vol. 13, no. 12, pp. 2210-2251, 2013.

[76] F. Jahanpeyma, M. Forouzandeh, M. J. Rasaee, and N. Shoaie, "An enzymatic paper-based biosensor for ultrasensitive detection of DNA," Frontiers in Bioscience (Scholar Edition), vol. 11, pp. 122-135, 2019.

[77] M. Mirasoli, A. Buragina, L. S. Dolci et al., "Chemiluminescence-based biosensor for fumonisins quantitative detection in maize samples," Biosensors and Bioelectronics, vol. 32, no. 1, pp. 283-287, 2012.

[78] G. A. Posthuma-Trumpie, J. Korf, and A. van Amerongen, "Development of a competitive lateral flow immunoassay for progesterone: influence of coating conjugates and buffer components," Analytical and Bioanalytical Chemistry, vol. 392, no. 6, pp. 1215-1223, 2008.

[79] Z. Guo, Y. Kang, S. Liang, and J. Zhang, "Detection of $\mathrm{Hg}$ (II) in adsorption experiment by a lateral flow biosensor based on streptavidin-biotinylated DNA probes modified gold nanoparticles and smartphone reader," Environmental Pollution, vol. 266, Article ID 115389, 2020.

[80] N.-S. Li, Y.-T. Chen, Y.-P. Hsu et al., "Mobile healthcare system based on the combination of a lateral flow pad and smartphone for rapid detection of uric acid in whole blood," Biosensors and Bioelectronics, vol. 164, Article ID 112309, 2020 . 